\title{
Investigation of the prevalence of Babesia canis in dogs in the center of Antalya province
}

\author{
Research Article \\ Volume: 4, Issue: 3 \\ December 2020 \\ Pages: 145-149
}

\author{
Mahmut KESKIN ${ }^{1}$, Kenan SEZER ${ }^{2 *}$, \\ 1. Altnkum Animal Hospital, 07100 , Altnkum, Antalya, Turkey \\ 2. Department of Internal Medicine, Faculty of Veterinary Medicine, Burdur Mehmet Akif Ersoy University, \\ 15030, Burdur, Turkey. \\ Keskin M. ORCID: 0000-0003-4343-5840. Sezer K. ORCID: 0000-0002-7413-5966.
}

\section{Article History}

Received: 30.9.2020

Accepted:16.12.2020

Available online:

18.12.2020

\begin{abstract}
This study was conducted to investigate the prevalence of Babesia canis in Antalya province For this purpose, the blood samples were taken from 200 dogs in the Antalya city centre, the examples were studied by the immune fluorescence antibody test (IFAT). In the study fluo Babesia canis (Biopronix/Italy) test kit was used, 1/32 and higher titters were considered positive. The 37 out of 200 serum samples (18.5\%) were found positive for Babesia canis as results of IFA test. As a result; Babesia canis positivity by serological method in dogs in Antalya, which gives an idea about the prevalence of the disease in this province, it would be useful to continue similar studies, using the specific identification method in the wider population.
\end{abstract}

Keywords: Babesia canis, IFAT, dog

DOI: https://doi.org/10.30704/http-www-jivs-net.802265

To cite this article: Keskin, M., \& Sezer, K. (2020). Investigation of the prevalence of Babesia canis in dogs in the center of Antalya province. Journal of Istanbul Veterinary Sciences, 4(3), 145-149. Abbreviated Title: J Ist Vet Sci

\section{Introduction}

Babesiosis is a disease of tropical and subtropical mild climate regions and it appears on wild carnivores as well as dogs (Uilenberg, 2006; Inci et al., 2010; Irwin, 2010)

The parasites transmitted from one animal to another by Ixodidae tick type, related to Babesia species, take place near the top of the blood protozoon of the dogs (Inci et al., 2010; Irwin, 2010; Kahn, 2005).

$B$. canis canis is transmitted by Dermacentor reticularis in Europe, $B$. canis vogeli is transmitted by Rhipicephalus sanguineus in tropical and subtropical countries, $B$. canis rossi is transmitted by Haemaphysalis leachi in South Africa (Boozer and Macintire, 2003; Kahn, 2005). Also in Turkey, Rhipicephalus sanguineus transferred $B$. canis vogeli shows a wide spread and this suggests that babesiosis on dogs is very common (Mimioglu, 1954; Güler, 1982; Inci et al., 2010).

The types of pathogens in dogs are $B$. canis (2.5X5.0 $\mu \mathrm{m})$ and $B$. gibsoni $(0.5 \times 3.5 \mu \mathrm{m})$ (Boozer and Macintire, 2003; Bilal, 2013). Babesia canis has been subdivided into three subspecies which are $B$. canis canis, B. canis vogeli and B. canis rossi (Boozer and Macintire, 2003; Inci et al., 2010). The occurrence of the disease and incubation time change between 10 and 21 days and that changes according to pathogen types and strains (Uilenberg, 2006; Inci et al., 2010). Although babesiosis appears in all dogs, it's suggested that the susceptibility to infection is higher in younger dogs. Rottweiler, greyhounds, pit bull terrier and American staffordshire terrier race dogs (Birkenheuer et al., 2004; Mathe et el., 2006). It has been reported because of pre-immunization, asymptomatic carrier dogs are more resistance than the dogs completely free from interference about getting infected again (Brandao et al., 2003).

Although it's thought many infected dogs are subclinical carrier, course of the babesiosis disease is per acute, acute and chronic (Freeman et al., 1994). Babesisosis is a disease that is characterized by lethargy, high fever (40-41.3 0C) hemolytic anemia

*Corresponding Author: Kenan Sezer

E-mail: ksezer@mehmetakif.edu.tr

Journal home page: www.jivs.net http://dergipark.gov.tr/http-www-jivs-net 
body weight loss, myositis, muscle tremors, lymphadenopathy, loss of appetite, depression, sweating, vomiting, icterus, hemoglobinuria, thrombocytopenia, coagulation disorders, acute respiratory distress syndrome, cerebral disorder immune deficiency, liver and acute renal failure. (Conrad et al., 1991; Kahn, 2005; Daste et al. Gökçe et al., 2013; Eichenberger, 2016)

As clinical course of the babesiosis in dogs is in two different forms as complicated (hemolysis and with anemia) and uncomplicated systemic inflammation syndrome (SIRS) and multiple organ failure syndrome (MODS) (Jacobson and Clark, 1994; Mrljak et al., 2014). Chronic form is defined as prolonged recovery at anemia and moderate depression (Bilal, 2013). Organ failure, mortality rates and causes in babesiosis are shown in Table 1.

Peripheral blood smear is used in the diagnosis of animals with clinical symptoms, and the immune fluorescent antibody (IFAT) test is used in the diagnosis of latent infections (Furuta et al., 2009).

Imidocarb dipropionate $(6 \mathrm{mg} / \mathrm{kg})$ is used in the treatment, and tetracycline preparations are added to the treatment in mixed infections (Freeman et al., 1994; Vercammen et al., 1995; Brandao et al., 2003; Bourdoiseau, 2006; Vial and Gorenflot, 2006). Complementary treatments include intravenous fluid and blood transfusion (Kahn, 2005; Bourdoiseau, 2006; Inci et al., 2010).

The vaccine should be administered alone or in combination with acaricidal drugs in dogs that have never been infected before, when tick activity is low (Uilenberg, 2006; Inci et al., 2010). The dogs with B. canis or B. gibsoni detected in their blood serologically or microscopically should not be used in blood transfusion (Taboada, 1998).

Since there are very few studies on babesiosis in dogs in Turkey, the prevalence of this disease is not fully known (Ulutas et al., 2005; Selek and Gargilı, 2006).

Although there are many studies about babesiosis in cattle, sheep and goats in Turkey, studies on dogs are very limited. Babesiosis on dogs can often be overlooked in the clinic because of its subclinical or atypical course. Therefore, the prevalence of babesiosis in dogs in Turkey is not fully known (Ulutas et al., 2005; Selek and Gargil, 2006). In this study, it was aimed to investigate the prevalence of $B$. canis in dogs in Antalya province.

\section{Materials and Methods}

This study was carried out on 200 dogs, 45 of them being owned, 155 living in shelter in Antalya city center. Of these dogs, 110 were female and 90 were male. In addition, of the 45 owner dogs, 11 were 3 years old, 20 were 4 years old, 6 were 5 years old, and 8 were 6 years old. The ages of 155 dogs living in the shelter could not be determined.

In this study, $5 \mathrm{ml}$ of blood was taken from each dog into gel vacoutainer tubes from vena cephalica for serum samples. After waiting for one night in the lab, blood samples into the sterile vacutainer tubes were centrifuged for $3000 \times 10$ min by circumferences by drawing with a sterile wire. So their serums were removed. Obtained serum samples, places in to the $1.5 \mathrm{ml}$ eppendorf tubes, have been maintained in

Table 1. \% Rates and causes of death of organ failures seen in babesiosis

\begin{tabular}{lllll}
\hline \multicolumn{1}{c}{$\begin{array}{c}\text { Inflammation and failure seen in organs } \\
\text { and systems }\end{array}$} & \multicolumn{3}{c}{ \% Rate } & \multicolumn{2}{c}{$\begin{array}{c}\text { Cause of } \\
\text { death( \%) }\end{array}$} \\
\hline Acute renal failure (ARF) & $30-71.4$ & 30 & \multicolumn{1}{c}{ References } \\
& & & $\begin{array}{l}\text { Mathe et al., 2006; Camacho et al., } \\
\text { Liver inflammation and insufficiency }\end{array}$ \\
Cerebral disorder (SB) & $24-42.8$ & 24 & Mathe et al., 2006; Crnogaj et al., 2010 \\
Disseminate intravascular coagulopathy (DIC) & 17 & 17 & Mathe et al., 2006 \\
Multiple organ failure (MODS) & 16 & 16 & Mathe et al., 2006 \\
Acute pancreatitis (AP) & 5 & 6 & Mathe et al., 2006 \\
Acute respiratory distress syndrome (ARDS) & $6-14.2$ & 6 & Mathe et al., 2006; Crnogaj et al., 2010 \\
Hemolytic anemia & $8-78$ & 8 & Mathe et al., 2006; Camacho et al., \\
Septic shock & 2.6 & & 2004 \\
\hline
\end{tabular}


$-20^{\circ} \mathrm{C}$ until using at the immunofluorescent antibody test (IFAT). In the study, Fluo $B$. canis (Biopronix/Italy) test kit was used and $1 / 32$ titer and above was accepted as positive. $B$. canis antigen slides, conjugate positive and negative control serums, glycerol and PBS tablet, which are necessary for IFA test, are provided from fluo $B$. canis.

Control items used in IFA test: The negative and positive control serum used in the study was obtained from biopronix (Biopronix/Italy), and also included in the PBS control.

Application of IFAT: The serum samples to be used in the study were taken from the deep freezer $\left(-20^{\circ} \mathrm{C}\right)$ in the laboratory the day before and placed in the refrigerator $\left(+4{ }^{\circ} \mathrm{C}\right)$. Antigen preparations was taken from the refrigerator $\left(+4{ }^{\circ} \mathrm{C}\right) 30$ minutes before starting the test and kept at room temperature. In the laboratory, each of the serum samples were diluted $1 / 32$ with PBS on microtiter plates according to the method. After the antigen preparations were numbered, they were placed in a humid environment (the humid environment was prepared by placing a filter paper in a lidded container and then dripping distilled water on it), then $10 \mu$ of diluted serum samples were dropped into each indent in the antigen preparations. Following these processes, the lid of the cuvette was closed and left for incubation at $37{ }^{\circ} \mathrm{C}$ for 30 minutes. Then the preparations were washed with PBS once by hand for 5 minutes, twice on a magnetic stirrer. Washed preparations were lined up again in the cuvette, one drop of each conjugate was dropped into each indent and the preparations were again left at $37{ }^{\circ} \mathrm{C}$ for 30 minutes. Then the preparations were washed with PBS once by hand for 5 minutes, twice on a magnetic stirrer. After this process, 2-3 drops of glycerin buffer were dropped on each preparation and covered with lamella. The preparations prepared were examined in the dark room with a 40-inch neofluar lens of a fluorescent microscope.

The degrees of "+" positivity used in the evaluation of the test were determined according to the intensity and clarity of the glare given by the preparation in the fluorescent microscope.

+++: perfect positivity

++ : good positivity

+ positivity

-: negative (no fluorescence)

Statistical analysis: All statistical analysis was performed using the SPSS-software program (Version 11.5.2.1, SPSS Inc., Chicago, IL, US.). The data obtained in the study were analyzed using the Chi-square $\left(\chi_{2}\right)$ test in the SPSS program.

\section{Results and Discussion}

Ten of the dogs were brought to our clinic for diarrhea, 8 for cough and 12 for dermatological problems. In addition, no significant clinical signs were observed in dogs in shelter.

At the IFA test result 37 of 200 serum samples which are taken from dogs included in the study has been identified as positive for $B$. canis and according to this $B$. canis prevalence of dogs in the Antalya province has been identified as $18.5 \%$.

First time, in 1893, it was mentioned from B. Canis on dogs, transmissing by Dermacentor, Rhipicephalus or Haemaphysalis tick type in Italy by Piana and GaliValerio and this is known big babesia of dogs (Mehlhorn and Schein, 1984).

The first case of babesiosis in our country was found on a beef by Mr. Nicoll and Adil in 1890 and the other studies followed this (Inci et al., 2010). In Turkey very little work has been done about prevalence of babesiosis in dogs (Ulutas et al., 2005; Selek and Gargill, 2006).

In a study around Aydın province (Tuna and Ulutaş, 2008 ), infection rate of $B$. canis was found as $1.8 \%$, on the other hand in a PCP-RLB study (Kırlı and Karagenç, 2006), around Aegean region, this rate was found as $10.44 \%$. In the microscopic PCB-RLB study on dogs in İstanbul (Selek and Gargilı, 2006), prevalence of babesiosis has been identified as $3.9 \%$. In a real time PCR study (Düzlü et al., 2014) on dogs in Kayseri province, prevalence of $B$. canis canis, B. gibsoni and B. canis vogeli was identified as $12 \%, 9 \%$ and $2.3 \%$ respectively. In this study, the prevalence of $B$. canis was identified as $18.5 \%$ and it has been seen that this rate is higher than istanbul province and Aegean region's rate and also near to obtained results of Kayseri province. It was thought that our high results comparing with other studies done in our country is related with the activation of vector ticks in a longer time du to Antalya's hot weather and many samples were taken from the same shelter where animals are in bulk. This result supports the assumption that climate and ecosystem in the Mediterranean region prepare a suitable environment for activation of actual tick type Rhipicephalus sanguineus on dogs all year around (Lorusso et al., 2010; Otranto and DantasTorres, 2010). The common possibility of potential tick infections on the stray dogs without tick control and parasitic spraying and tick borne infections are evaluated as supportive factors. 


\section{Conclusion}

As a result of the study, it was concluded that Babesia canis positivity detected in dogs in Antalya by serological method, gives an idea about the prevalence of the disease in this province, and It would be useful to continue similar studies in larger populations by specific diagnosis methods towards the agent.

\section{Acknowledgments}

We thank Burdur Mehmet Akif Ersoy University, Coordinatorship of Scientific Research Projects for all their support to this research.

\section{References}

Bilal T. (2013). Kedi köpek iç hastalıkları. Istanbul, Turkey, Nobel Tıp Kitabevi.

Biopronix, Fluo Babesia canis. Agrolabo diagnostic products. Catalogue for Cats, Dogs, and Horses. Code: 27263601 Scarmagno (TO) Italy

Birkenheuer, A. J., Neel, J., Ruslander, D., Levy, M.G., \& Breitschwerdt, E. B. (2004). Detection and molecular characterization of a novel large Babesia species in a dog. Veterinary Parasitology, 5,151-160.

Boozer, A. L., \& Macintire, D. K. (2003). Canine babesiosis. Veterinary Clinics of North America: Small Animal Practice, 33, 885-904.

Bourdoiseau, G. (2006). Canine babesiosis in France. Veterinary Parasitology, 138, 118-125.

Brandao, L. P., Hagiwara, M. K., \& Myiashiro, S.I. (2003). Humoral immunity and reinfection resistance in dogs experimentally inoculated with Babesia canis and either treated or untreated with imidocarb dipropionate. Veterinary Parasitology, 114, 253-265.

Camacho, A. T., Guitian, E. J., Pallas, E., Gestal, J. J., Olmeda, A. S., Goethert, H. K., Telford, S. R., \& Spielman, A. (2004). Azotemia and mortality among Babesia microti-like infected dogs. Journal of Veterinary Internal Medicine, 18(2), 141-146.

Conrad, P., Thomford, J., Yamane, I., Whiting, J., \& Bosma, L. (1991). Hemolytic anemia caused by Babesia gibsoni infection in dogs. Journal of the American Veterinary Medical Association, 199, 601-605.

Crnogaj, M, Petlevski, R. Mrljak, V, Torti, M, Kucer, N, Matijatko, V, Sacer, I., \& Stokovic, I. (2010). Malondialdehyde levels in serum of dogs infected with Babesia canis. Journal Veterinarni Medicina, 55 (4),163-171.

Daste, T., Lucas, M. N., \& Aumann, M. J. (2013).
Cerebral babesiosis and acute respiratory distress syndrome in a dog. Journal of Veterinary Emergency \& Critical Care) 23, 615-623.

Düzlü, Ö, Inci, A., Yıldırım, A., Onder, Z., \& Çiloğlu, A. (2014). Köpeklerde kene kaynaklı bazı protozoon ve rickettsial enfeksiyonların Real Time PCR ile araştrılması ve saptanan izolatların moleküler karakterizasyonları. Ankara Üniversitesi Veteriner Fakültesi Dergisi, 61, 275-282.

Eichenberger, R. M., Riond, B., \& Willi, B, HofmannLehmann, R., Deplazes, P. (2016). Prognostic markers in acute Babesia canis infections. Journal of Veterinary Internal Medicin, 30, 174-182.

Freeman, M. J., Kirby, B. M., Panciera, D. L., Henik, R. A., Rosin, E., \& Sullivan, L. J. (1994). Hypotensive shock syndrome associated with acute Babesia canis infection in a dog. Journal of the American Veterinary Medical Association, 204, 94-96.

Furuta, P. I., Oliveira, T. M. F. S., Teixeira, M. C. A,. Rocha, A. G., Machado, R. Z., \& Tinucci-Costa, M. (2009). Comparison between a soluble antigenbased ELISA and IFAT in detecting antibodies against Babesia canis in dogs. Brazilian Journal of Veterinary Parasitology, 18, 41-45.

Gökçe, E., Kırmızıgül, A. H., Taşçı, G. T., Uzlu, E., Gündüz, N., \& Vatansever, Z. (2013). Türkiye'de köpeklerde Babesia canis canis'in klinik ve parazitolojik olarak ilk tespiti. Kafkas Üniversitesi Veteriner Fakültesi Dergisi, 19, 717-720.

Güler, S. (1982). Ankara ve civarındaki koyun ve keçilerde kış Ixodide'leri üzerine araştırmalar. Uludağ Üniversitesi Veteriner Fakültesi Dergisi, 1, 45 -54 .

Inci, A., Düzlü, Ö., \& Iça, A. (2010). Babesiidae. In Dumanli N, Karaer Z. (Ed). Veteriner protozooloji, 1. baskı, Ankara. Turkey Medisan Yayınevi.

Irwin, P. J. (2010). Canine babesiosis. Veterinary Clinics of North America: Small Animal Practice, 40, 11411156.

Jacobson, L. S., \& Clark, I. (1994). The pathophysiology of canine babesiosis: new approaches to an old puzzle. Journal of the South African Veterinary Association, 65, 134-145.

Kahn CM. (2005). The Merck Veterinary Manual, 9th ed. Merck \& Co. Inc. New Jersey.

Kırlı, G., \& Karagenç, T. (2006). Ege bölgesinde köpek babesiosisinin yaygınlığı. Yüksek Lisans Tezi, Aydın: Adnan Menderes Üniversitesi, Sağlık Bilimleri Enstitüsü. Türkiye 
Lorusso, V, Dantas-Torres, F, Lia, R. P., Tarallo, V. D, Vial, H. J., \& Gorenflot, A. (2006). Chemotherapy Mencke, N., Capelli, G., \& Otranto, D. (2010). against babesiosis. Veterinary Parasitology, 138, 147 Seasonal dynamics of the brown dog tick. -160 .

Rhipicephalus sanguineus, on a confined dog

Mathe, A., Vörös, K., Papp, L., \& Reiczigel, J. (2006). Clinical manifestations of canine babesiosis in Hungary (63 cases). Acta Veterinaria Hungarica, 54, 367-385.

Matijatko, V., Kis, I., Torti, M., Brkljacić, M., Kucer, N., Rafaj, R. B., Grden, D., Zivicnjak, T., \& Mrljak, V. (2009). Septic shock in canine babesiosis. Veterinary Parasitol, 10(162), 263-270.

Mehlhorn H., \& Schein E. (1984). The piroplasm: Life cycle and sexual stages. Advances in Parasitology, 23, 37-103.

Mimioğlu, M. (1954). Die Schildzecken (Ixodidade) der haustiere in der Türkei, Ankara Üniversitesi Veteriner Fakültesi Dergisi, 1, 20-35.

Mrljak, V., Kučer, N., Kuleš, J., Tvarijonaviciute, A., Brkljačić, M., Crnogaj, M., Zivičnjak, T., Smit, I., Ceron, J. J., \& Rafaj, R. B. (2014). Serum concentrations of eicosanoids and lipids in dogs naturally infected with Babesia canis. Veterinary Parasitology, 201(1-2), 24-30.

Otranto, D., \& Dantas-Torres, F. (2010). Canine and feline vector-borne diseases in Italy: current situation and perspectives. Parasitology, 3, 1-12.

Selek, N. A., Gargılı, A. (2006). İstanbul ili köpeklerinde bulunan Babesia türlerinin teşhisinde mikroskobik ve PCR-RLB bulgularının karşılaştrııması. Doktora Tezi, İstanbul: İstanbul Üniversitesi Sağlık Bilimleri Enstitüsü,

Taboada J. 1995. Canine babesiosis, (pp 315-319). In Bonagura JD (ed): Kirk's current veterinary therapy: XII. Small animal practice. Philadelphia. US: WB Saunders.

Tuna, G. E., \& Ulutaş, B. (2008). Trombositopenili köpeklerde Ehrlichia canis ve Babesia canis enfeksiyonlarının prevalansı. Yüksek Lisans Tezi, Aydın Adnan Menderes Üniversitesi, Aydın, Turkey.

Uilenberg G. (2006). Babesia-a historical overview. Veterinary Parasitology, 138, 3-10.

Ulutaş, B, Bayramlı, G., Ulutaş, P. A., \& Karagenç, T. (2005). Serum concentration of some acute phase proteins in naturally occurring canine babesiosis: a preliminary study. Vet Clin Pathol 34, 144-147.

Vercammen, F, De Deken, R., \& Maes, L. (1995). Clinical and serological observations on experimental infections with Babesia canis and its diagnosis using the IFAT. Parasitology, 2, 407-410. 